\title{
DITORIAL
}

Jeanne Marie Machado de Freitas $\boldsymbol{\square}$

\section{terceiro ano: noventa e três artigos publicados}

CALIGRAMA é um lugar de escrita construído ao longo de uma história que começa ainda no século passado. Precisamente em 1993, quando as agências financiadoras (CNPq, CAPES, FAPESP) apoiaram pesquisas que se postavam em um campo de saberes transversais até então não oficializado: o campo das Ciências da Linguagem. $\bigcirc$ rotineiro nos estudos da comunicação e das mídias abrigava-se no conhecimento instituído sob o rótulo das Ciências Sociais (aplicadas, completava o rótulo). É bem verdade que a rotulação continua a mesma, mas a direção se transformou no esforço da transversalidade e na violação das fronteiras disciplinares.

Foi então, em 1993, que a criação do Núcleo Permanente de Estudos Jornalismo e Linguagem, NUPJL, sediado no Departamento de Jornalismo e Editoração, da Escola de Comunicações e Artes, da Universidade de São Paulo, marcou o início do projeto que visava à introdução das Ciências da Linguagem no fundamento dos estudos da comunicação.

O núcleo surgiu na seqüência de uma reformulação do Programa de PósGraduação, vinculado a um projeto coordenado pelo Professor José Marques de Melo: A Práxis Jornalística Brasileira: Impacto das Inovações Tecnológicas e do Paradigma Democrático (1945-1995). Em torno do projeto articulavam-se vários outros núcleos de pesquisa.

Os pesquisadores integrantes do NUPJL desenvolveram (de março de 1993 a fevereiro de 1996) os seguintes subprojetos integrados àquela pesquisa: Jornalismo, a Busca de um Destino, de Jeanne Marie Machado de Freitas; Texto e Imagem na Narrativa Informativa, de Dulcília Helena Schroeder Buitoni; O Jornalismo Brasileiro e sua Práxis Textual: Práticas Discursivas e Narrativas, de Maria do Socorro Nóbrega; e A Evolução dos Gêneros no Discurso da Imprensa Diária Brasileira, de Manuel Carlos da C. Chaparro.

A circulação da palavra, o que equivale a dizer, a sedimentação de um campo, realizava-se em reuniões que aconteciam na última quinta-feira de cada mês do período. Encontravam-se: os professores do Núcleo, os alunos de iniciação científica, os alunos de pós-graduação, palestrantes convidados. Trabalhava-se aí algo que resultou, na linha do tempo, em modificações no currículo dos cursos de comunicação e nas propostas e orientações das pesquisas. Enfim, construíase um novo modo de pensar a comunicação. 
A etapa seguinte (março de 1996 a fevereiro de 2000) consolidou a proposta, com o desenvolvimento do Projeto Integrado de Pesquisa: A Globalização da Comunicação. A Desterritorialização da Cultura. A Tecnologia. A discussão dos problemas na referência da Linguagem atraiu e implementou projetos de pesquisa dos alunos de pós-graduação, favorecendo o estudo das redes midiáticas e a compreensão de um dos objetos centrais da contemporaneidade -a televisão.

A proposta de registro do que chamávamos work in progress concretizouse nas páginas de Nexus, newsletter que circulava não somente entre os integrantes do Núcleo, mas buscava leitores nas diferentes escolas de comunicação. Era insuficiente, pois a demanda crescia. Vários projetos de revista impressa surgiram. Mas talvez tivéssemos sido incapazes de levá-los avante, principalmente pelos obstáculos financeiros.

Foi então que, em 2005, um grupo formado por estudantes da pósgraduação, integrantes do Núcleo, cujos nomes estão inscritos nos primeiros números da revista, produziram a revista on-line, marcada pela inigualável programação visual de autoria de Jorge Arbach, também participante do grupo.

O nome CALIGRAMA, a indicar o texto escrito que porta, na raiz, a marca da beleza, cali, diferenciou a publicação: reúne a abertura que o belo promete, pois que o belo vai além das barreiras do bem e do útil, barreiras que contêm a ciência bem-comportada, como ensina Lacan, e atinge o lugar marcado pelo interdit-d'y-penser, que as Ciências da Linguagem permitem vislumbrar.

Assim, depois de vários percalços, aqui estamos e pretendemos permanecer, integrando todos os que, insatisfeitos com a banalidade de alguns estudos da área de comunicação, aceitam a proposta, ousada, de repensar aquilo que artefaz o mundo hoje: as mídias, nos seus inúmeros desdobramentos.

Não é por acaso que CALIGRAMA V.3, N.3 inicia com o trabalho de dois professores que integravam o grupo. A publicação visa a preservar-lhes a memória, prestando-lhes, deste modo, uma homenagem póstuma.

O primeiro trabalho, de autoria do Professor Eduardo Leone, trata da narrativa na edição cinematográfica. É importante dizer que o professor, nas suas aulas e nos seus trabalhos (raramente publicados) inovou o modo de pensar o próprio fazer fílmico. $\mathrm{O}$ artigo é extraído do projeto, que foi concluído, integrado à pesquisa sobre a globalização, intitulado Um Laboratório de Dramaturgia Cinematográfica: As Influências Expressivas das novas Tecnologias nas Narrativas: os Filmes Produzidos por Steven Spielberg. O produtor era uma das grandes paixões de Leone, traço apreensível na sua escrita.

O segundo é o projeto inconcluso, proposto pelo Professor Carlos Marcos Avighi, vinculado à mesma pesquisa sobre a globalização. $O$ texto desenvolve uma singular discussão sobre as modificações que a editoria internacional dos periódicos vêm sofrendo, sob o efeito dos processos globalizadores, e postula uma elaboração conceitual capaz de apreender a transformação e nortear o ensino.

Na seqüência, L. S. de Lima Pinheiro, da Universidade do Estado da Bahia, retoma a discussão entre texto e imagem, baseando-se nos estudos de R. Barthes e U. Eco; L. F. Dória, da Faculdade de Artes do Paraná, analisa, no filme o Homem que Copiava, as relações entre as proposições estéticas pós-modernas e a construção da identidade nacional; o atual embate discursivo sobre a pesquisa com células-tronco embrionárias é o tema apresentado por J. A. de Oliveira, da Universidade Metodista de São Paulo; M. G. Neira, professor da Faculdade de Educação da Universidade de São Paulo, com pós-doutorado na Universidade do Minho, Portugal, e M. L. F. Nunes, docente do Curso Universitário ÍtaloBrasileiro, ambos do Grupo de Pesquisa em Educação Física Escolar (CNPq), 
propõem o estudo do movimento humano como linguagem, vinculando-o à pedagogia da cultura corporal, à semiótica e aos processos de constituição de identidade; A. C. de Carvalho e F. de Assis, professores da Universidade de Taubaté, enfrentam as dificuldades de definição do hipertexto e apresentam alguns caminhos para a construção de um método de ensino; jornalista especializada em Comunicação e Saúde, pela Fundação Oswaldo Cruz, e mestra em memória social, pela Universidade Federal do Rio de Janeiro, S. Vaisman analisa os informativos da área de comunicação em instituições ligadas à biomedicina, considerando-os como lugares emblemáticos para investimentos políticos; C. R. Riolfi, psicanalista e professora da Faculdade de Educação da Universidade de São Paulo, e S. G. da Igreja, graduanda em Letras, ambas integrantes do Grupo de Estudos e Pesquisa Produção Escrita e Psicanálise (CNPq) buscam construir um modelo de representação que dê conta do ato de escrever e se reporte ao produtor do texto, ao jornalista e ao leitor que procura modelos para balizar o seu próprio texto; V. Costa, pós-doutorando em História Social, da FFLCH da Universidade de São Paulo, estabelece correlações entre a teoria das representações, as Ciências da Linguagem e a Semiótica, no suposto de que habitam um território comum.

Na seção ARQUIVO, CALIGRAMA foi buscar na revista New Yorker o artigo de Eric Alterman, "Out of Print The Death and Life of the American Newspaper". Republica-o, com a autorização da Conde Nast, editora da revista, por julgar que apresenta uma discussão atual sobre a imprensa e a Internet.

O Efêmero e o Perpétuo na Fotografia, de J. R. Martins, jornalista e mestre em História da Fotografia, pela ECA, Universidade de São Paulo, é uma interessante RESENHA do livro do Professor Boris Kossoy, convidando à sua leitura.

Por fim, CALIGRAMA apresenta uma indexação dos seus três volumes publicados, desde 2004, para cumprir a exigência editorial e facilitar a busca de seus leitores.

E terminamos com um apelo: junte-se a nós. 